\title{
DINAMIKA GENDER DALAM MASYARAKAT
}

\section{Fatimah Saguni}

\begin{abstract}
The status and roles of women produce various conclusions due to different perspectives and approaches in examining gender relations and the dynamics of interactions that occur in gender relations in society. Biological differences between men and women have occurred since the conception, embryological development and puberty. Socioculturally, these differences are developed in accordance with the conditions that occur among the ethnic groups concerned.

This shift can be seen in the increasing number of women who penetrate the public sphere, even willing to leave their homes to get work. Differences in gender roles that are formed by society are continuously socialized through education, either directly or indirectly in families, schools and in the community. Therefore, society really adheres to the rules that differentiate the roles of women and men. For this reason, various efforts are needed to fight for gender equality in people's lives.
\end{abstract}

Keywords: Gender dynamics, Public.

\section{PENDAHULUAN}

Peran penting perempuan ditunjukkan dengan adanya kenyataan bahwa disebagian rumah tangga perempuanlah yang mengelola pendapatan dan pengeluaran rumah tangga. Disamping itu perempuan juga berperan penting dalam proses pengambilan keputusan. Hal ini berbeda dengan keadaan dan status perempuan di negara-negara sedang berkembang lainnya, seperti Bangladesh, India dan Cina. Faktor ini menunjukkan bahwa perempuan mempunyai akses yang cukup besar terhadap berbagai jenis sumber daya ekonomi, sosial dan kultural merupakan faktor-faktor yang sangat penting dalam menentukan status dan peran perempuan.

Hampir semua pekerjaan yang selama ini hanya dikerjakan kaum laki-laki dan ditabuhkan bagi mereka, kini bisa dan lumrah dikerjakan oleh kaum perempuan. Pergeseran ini dapat dilihat melalui semakin banyaknya jumlah perempuan yang merambah wilayah publik, bahkan rela meninggalkan rumah untuk memperoleh pekerjaan. Hal ini dibuktian dengan diadakannya Konferensi Perempuan IV Sedunia di Beijing pada tahun 1995 yang merumuskan tentang penolakan terhadap ajaran agama yang memandang eksistensi perempuan dengan sebelah mata dan Konferensi 
Durban pada tahun 2001 tentang diskriminasi gender. ${ }^{1}$ Kesadaran gender telah membuka ruang kesataraan antara suami dan istri dalam posisi equal dalam persoalan hak dan kewajiban dalam menjalankan kehidupan rumah tangga. Tanggungjawab perlindungan, keamanan, kesejahteraan, dan nafkah untuk keluarga yang dulu berada dipundak laki-laki, kini juga telah diperankan oleh perempuan.

Tidak dapat disangkal lagi bahwa partisipasi masyarakat di dalam kegiatan pembangunan sangatlah penting dan bahkan menentukan. Diskriminasi gender dalam berbagai hal di kehidupan bermasyarakat menimbulkan perbedaan capaian antara laki-laki dan perempuan. Di wilayah yang masih kental akan budaya patriarki, perempuan umumnya lebih tertinggal dari laki-laki baik di bidang kesehatan, pendidikan dan ekonomi. Hal ini terjadi karena norma yang ada pada budaya patriarki seringkali merugikan perempuan dengan menempatkannya sebagai warga kelas dua. Kesepakatan secara internasional seperti Konvensi Penghapusan Segala Bentuk Diskriminasi Terhadap Perempuan/Convention on the Elimination of All Forms of Discrimination Against Women (CEDAW) dan Beijing Declaration and Platform for Action (BDPA). Bermaksud menjawab persoalan yang dialami perempuan, CEDAW secara tegas memberikan kewajiban kepada negara untuk memperbaiki kebijakan, hukum, dan mengambil langkah-langkah yang dianggap perlu untuk memperbaiki kondisi perempuan. ${ }^{2}$

Kini, isu gender menjadi salah satu hal penting yang dicantumkan dalam berbagai dokumen perencanaan pembangunan, baik pada tingkat nasional maupun global. Isu gender menjadi salah satu poin dalam tujuan pembangunan berkelanjutan/ Sustainable Development Goals (SDGs). Gender merupakan isu yang bersifat multidimensi. Isu ini meliputi sisi kesehatan, pendidikan dan ekonomi yang juga menjadi fokus SDGs. Selain secara khusus dicantumkan dalam tujuan kelima, isu gender juga tercakup pada hampir seluruh tujuan dalam pembangunan

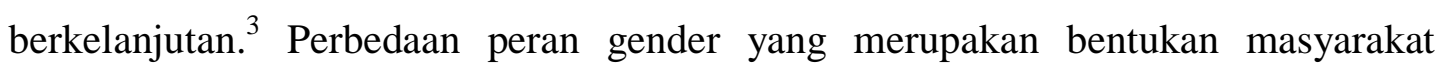

\footnotetext{
${ }^{1}$ A. Fitri. Balasong,. Imaji; Sketsa Pergelakan Batin Perempuan. (Cet. I. Makassar: Pustaka Sawerigading, 2008), 4

${ }^{2}$ Rini Maryam. Menerjemahkan Konvensi Penghapusan Segala Bentuk Diskriminasi Terhadap Perempuan (Cedaw) Ke Dalam Peraturan Perundang-Undangan, 100

${ }^{3}$ Pembangunan Manusia Berbasis Gender. https://www.kemenpppa.go.id/lib/uploads/list/6a89b-buku-pmbg-2018.pdf diakses tanggal 27 Desember 2020, xv
} 
disosialisasikan terus menerus melalui pendidikan baik secara langsung maupun tidak langsung dalam: keluarga, sekolah, dan dimasyarakat. ${ }^{4}$ Oleh karena itu masyarakat sangat memegang teguh aturan-aturan yang membedakan peran perempuan dan laki-laki.

\section{PEMBAHASAN}

Laju perkembangan gender dalam masyarakat bergerak cepat, sehingga diperlukan penelitian-penelitian yang mendalam dan khas. Ada kekhususan para peneliti gender yang jarang menyentuh pada aspek sumbangsih perempuan, peran perempuan, dan keberhasilan perempuan dalam mengubah peradaban zaman. Dalam penelitian harus mengungkap rahasia-rahasia dibalik persoalan yang akan diangkat, begitu juga ketika ingin meneliti mengenai gender. Peneliti harus menggali sampai pada titik kerahasiaan. Ada rahasia apa yang ada di ketimpangan sosial, rahasia perempuan dalam mengajukan kesetaraan gender. ${ }^{5}$

Ketidakadilan peran gender yang sudah membudaya akan mengakibatkan perempuan mengalami proses marginalisasi, subordinasi, stereotip keperempuanan yang cenderung negative, tindak kekerasan dan pelecehan serta beban kerja domestik yang terlalu banyak. Sementara itu gerakan menuju kesetaraan gender sering mendapat perlawanan dan hambatan karena ketidak mengertian mengapa status perempuan harus dipertanyakan, serta mengapa hak-hak istimewa yang dimiliki dan dinikmati laki-laki harus digugat. Kendala tersebut juga sangat berat, karena mempertanyakan status perempuan pada dasarnya adalah mempersoalkan system dan struktur masyarakat yang telah mapan selama ribuan tahun. Mengingat hambatan dan kendala tersebut, maka gerakan feminism sebagai gerakan untuk mengembalikan harkat dan martabat perempuan serta membebaskannya dari pelecehan, penderitaan dan beban-beban yang tidak proporsional, tuntutan-tuntutan yang berlebihan serta pemikiran-pemikiran reaktif yang sering menentang sunnatullah. Dekonstruksi ideologis dan sosiokultural yang ditawarkan haruslah melalui penyadaran yang

\footnotetext{
${ }^{4}$ Ulfatun Hasanah dan Najahan Musyafak. Gender And Politics: Keterlibatan Perempuan Dalam Pembangunan Politik. SAWWA - Volume 12, Nomor 3, Oktober 2017, 410

${ }^{5}$ Prof. Irwan Abdullah. Kupas Strategi Penulisan dan Penelitian Gender 2019. https://iainkudus.ac.id/temp/u01/list.php?pag=detail\&idb=56064, diakses tgl 27 Desember 2020.
} 
ikhlas. Proses yang harus melewati dimensi-dimensi kognitif, afektif, dan psikomotor sehingga mampu mengantisipasi problem gender secara kritis dan proporsional. ${ }^{6}$

Gerakan gender menjadi arus utama di negara-negara berkembang termasuk di Indonesia. Dalam proses demokratisasi, persoalan partisipasi politik perempuan yang lebih besar, reperesentasi dan persoalan akuntabilitas menjadi persyaratan mutlak bagi terwujudnya demokrasi yang lebih bermakna di Indonesia. Untuk itu diperlukan berbagai upaya untuk memperjuangkan kesetaraan gender dalam kehidupan masyarakat, yang nantinya diharapkan akan memberikan perubahan pandangan tentang budaya patriakhi bagi masyarakat, sehingga kemungkinan terpilihnya peminpin politik perempuan akan sama dengan kemungkinan terpilihnya pemimpin politik laki-laki. Sehingga kesetaraan gender dalam dunia perpolitikan akan semakin maju. ${ }^{7}$

Gender lebih ditekankan pada perbedaan peranan dan fungsi yang ada dan dibuat oleh masyarakat. Dalam realitas kehidupan telah terjadi perbedaan peran sosial laki-laki dan perempuan yang melahirkan perbedaan status sosial di masyarakat, di mana laki-laki lebih diunggulkan dari perempuan melalui konstruksi sosial. Perbedaan peran antara lakilaki dan perempuan yang tidak seimbang ini juga sangat dipengaruhi oleh budaya dan kultural masyarakat Indonesia yang terdiri dari banyak etnis dan suku. Setiap masyarakat suku di Indonesia mempunyai ciri khas tersendiri dalam memaknai peran gender di negara ini. Di Indonesia, isu kesetaraan gender akhir-akhir ini menjadi isu yang tidak ada habisnya dan masih terus diperjuangkan baik di tingkat eksekutif maupun legislatif. Permasalahan tentang kesetaraan gender ini mencakup substantif pemahaman tentang kebijakan perspektif gender itu sendiri. Peningkatan kesadaran dan pemahaman itu, harus dibarengi dengan adanya keterwakilan perempuan dalam lembaga-lembaga negara, terutama lembaga pembuat kebijakan. ${ }^{8}$

Selama ini, pemahaman masyarakat Indonesia merekonstruksi bahwa secara kodrat, perempuan lemah dan lakilaki kuat, sehingga untuk menjadi pemimpin dalam

\footnotetext{
${ }^{6}$ Mujahidah. Dinamika Gender Dan Peran Perempuan Dalam Ekonomi Keluarga. Jurnal AlUlum Volume. 10, Nomor 1, Juni 2010, 6.

${ }^{7}$ Wery Gusmansyah. Dinamika Kesetaraan Gender dalam Kehidupan Politik Di Indonesia. Jurnal Hawa : Studi Pengarus Utamaan Gender dan Anak. (Jurnal Hawa Vol 1, No 1, 2019), 156.

${ }^{8}$ Imam Mahdi. Konsep gender pada masyarakat adat suku semendo kabupaten muara enim (studi kasus pada adat tunggu tubang. (Jurnal Hawa Vol. 1 No. 1 Januari-Juni 2019, 159.
} 
sebuah keluarga tetap diserahkan kepada laki-laki. Hal ini menunjukkan dominasi laki-laki pada peran domestik. Keadaan tersebut menyebabkan posisi perempuan sarat dengan pekerjaan yang beragam, dalam waktu yang tidak terbatas, seperti memasak, mengurus rumah, mengurus anak, dan sebagainya. Pekerjaan domestik tersebut dilakukan bersama-sama dengan fungsi reproduksi. di Indonesia, disadari mempunyai arti yang masih diskriminatif terhadap perempuan. Pemerintah secara resmi telah menganut dan menetapkan kesepakatan atas persamaan antara perempuan dan lakilaki sebagaimana termuat dalam UUD 45 Pasal 27. Namun demikian, dalam perkembangannya, beberapa UU yang selama ini berlaku Seperti dalam UU mengenai sistem pengupahan tenaga kerja perempuan, tunjangan keluarga dan tunjangan kesehatan-perempuan dianggap lajang sehingga suami dan anak-anak tidak mendapatkan tunjangan sebagaimana yang diterima pekerja laki-laki.

Menurut Ulfatun Hasanah dan Najahan Musyafak bahwa perbedaan peran gender yang merupakan bentukan masyarakat disosialisasikan terus menerus melalui pendidikan baik secara langsung maupun tidak langsung dalam keluarga, sekolah, dan dimasyarakat. ${ }^{9}$ Lebi lanjut Amiruddin Mustam mengatakan bahwa perempuan selain memiliki keunggulan biologis alamiah, juga memiliki keunggulan social, yaitu perpaduan kualitas antara sifat peminim, seperti hangat, lembut penuh kasih sayang dan pengorbanan dengan sifat tegas, bertanggung jawab, kuat dan sebagainya. Pengakuan dan pengertian dunia terhadap pentinganya peranan perempuan dalam pembangunan terus meningkat, karena wanita merupakan kelompok yang mewakili separuh dari penduduk dunia, dan dari segi pembangunan. Hal ini berarti mereka merupakan lebih dari separuh pelaku pembangunan dan lebih dari separuh pemanfaat pembangunan. ${ }^{10}$

Munculnya isu ketidakadilan gender atau diskriminasi gender akibat adanya proses konstruksi sosial di dalam masyarakat. Padahal Islam dan UUD 45 negara telah menjamin kesetaraan akses perempuan dan laki-laki. Oleh karena itu, peningkatan peranan perempuan dan laki-laki dalam pembangunan yang berwawasan

\footnotetext{
${ }^{9}$ Ulfatun Hasanah dan Najahan Musyafak. Gender And Politics: Keterlibatan Perempuan Dalam Pembangunan Politik. SAWWA - Volume 12, Nomor 3, Oktober 2017, 410.

${ }^{10}$ Amiruddin Mustam. Budayagender Dalam Masyarakat Perspektiftemporal Ekologi Dan Sosial Ekonomi. Jurnal Al-Maiyyah, Volume 10 No. 1 Januari-Juni 2017, 186.
} 
gender sebagai bagian integral dari pembangunan nasional, mempunyai arti penting dalam upaya untuk mewujudkan kemitra sejajaran yang harmonis antara laki-laki dengan perempuan, kesetaraan dan keadilan gender dalam berbagai bidang kehidupan dan pembangunan.

Penelitian membuktikan bahwa pria dan wanita adalah sama dalam hal kemampuan belajar, daya ingat kemampuan penalaran, kreativitas dan kecerdasan. ${ }^{11}$ Meskipun hasil data Riset cukup memastikan, beberapa peneliti masih percaya adanya perbedaan kreativitas, penalaran dan kemampuan belajar diantara pria dan wanita. Keragaman digunakan untuk menjelaskan mutu manusia seperti ras, jenis kelamin dan etnis yang berbeda dari kelompok sendiri dan kelompok diluar dari tempat mereka berada. ${ }^{12}$

Posisi wanita Indonesia sejak dulu hingga sekarang hampir tidak banyak berubah, yakni masih mengalami perlakuan yang sangat berbeda denga pria. Mereka menjadi kelompok subordinat dan dalam berbagai hal sering dikalahkan oleh pria. Mereka harus mendengar berbagai larangan dan juga lebih banyak menerima aturan dibandingkan dengan pria. Perilaku mereka tidak pernah lepas dari pengawasan orang-orang di lingkungannya. Sejak kecil wanita telah menerima penjelasan ataupun aturan tentang mana yang boleh dan tidak boleh dilakukan oleh perempuan baik dari sisi kebudayaan, perdagangan dan dalam pembangunan.

\section{A. Perempuan dan Kebudayaan}

Struktur sosial masyarakat yang membagi-bagi tugas antara pria dan wanita seringkali merugikan perempuan. Perempuan diharapkan bisa mengurus dan mengerjakan berbagai pekerjaan rumah tangga, walaupun mereka bekerja di luar rumah tangga, sebaliknya tanggungjawab laki-laki dalam mengurus rumah tangga sangat kecil. Sebagian masyarakat beranggapan bahwa tugas-tugas kerumahtanggaan dan pengasuhan anak adalah tugas wanita, walaupun perempuan tersebut bekerja. Ada batasan tentang hal yang pantas dan tidak pantas dilakukan oleh laki-laki dan perempuan dalam menjalankan tugas-tugas rumah tangga. Perempuan kurang bisa

\footnotetext{
${ }^{11}$ J.S. Hyde and M.C. Linn, The Psychology of Gender. Advance through Meta-Analysis (Baltimore: Johns Hopkins University Press, 1986), 64.

${ }^{12}$ Gibson, Ivancevich, Donnell. Organisasi. Perilaku Struktur dan Proses. Edisi kedelapan, Jilid 1
} 
mengembangkan diri karena adanya pembagian tugas tersebut. Peran ganda laki-laki kurang bisa diharapkan karena adanya ideologi tentang pembagian tugas secara seksual.

Berangkat dari perbedaan jenis kelamin, sebuah konsep pembedaanpun lahir mengiringi kehidupan masyarakat. Format ini kemudian memunculkan konsekwensikonsekwensi gender antara kehidupan laki-laki dan perempuan. Ketika konsekwensikonsekwensi tersebut teraplikasi dalam kehidupan praksis, banyak perkara yang membuat perempuan sadar ataupun tidak termajinalkan lagi. Tidak diperhitungkannya perempuan dalam beberapa sektor menyebabkan munculnya aliranaliran feminisme yang saat ini mengawal wacana gender.

Perbedaan perlakuan terhadap laki-laki dan perempuan telah dimulai sejak mereka masih kanak-kanak. Anak perempuan diarahkan untuk bisa mengerjakan pekerjaan rumah tangga, seperti memasak, membersihkan lantai, mencuci, menyetrika baju dan mengasuh adik, sedangkan anak laki-laki seringkali dibiarkan bermain sesukanya. Laki-laki juga sangat jarang menerima larangan-larangan ataupun peringatan tentang bagaimana mereka sebaiknya bertingkah laku. Berbeda halnya dengan perempuan yang sangat sering menerima berbagai larangan. Perempuan dibatasi norma-norma sehingga tidak bisa berbuat sebebas laki-laki. Ada pendapat yang menyatakan bahwa perempuan sebaiknya tidak bepergian sendiri di malam hari. Bila itu dilakukan akan menimbulkan penilaian yang negatif dari masyarakat.

Peremuan seringkali dianggap sebagai orang yang paling berperan dalam pendidikan dan penerus nilai-nilai budaya bagi anak-anaknya. Sebagai orang yang harus meneruskan nilai-nilai bagi generasi muda, maka perempuan diharapkan mempunyai kepribadian dengan ciri-ciri seperti kehalusan, keagamaan, kesopanan dan lain sebagainya. Karena kewajiban itu harus dipikul oleh perempuan, sejak dini perempuan dipersiapkan untuk menjalankan tugas tersebut. Cara yang ditempuh untuk mewujudkannya adalah dengan memberikan pengajaran tentang nilai-nilai dan norma-norma yang berlaku dalam masyarakat, teristimewa kepada anak perempuan.

Perempuan seringkali dinomorduakan dalam hal pendidikan. Jika dalam suatu keluarga, orang tua ternyata tidak mampu membiayai sekolah semua anak- 
anaknya, mereka akan mendahulukan anak laki-laki. Laki-laki dipersiapkan untuk menjadi tiang keluarga nantinya, sedang perempuan hanya sebagai pengurus rumah tangga. Kalaupun mereka bekerja, hasilnya hanya dianggap sebagai tambahan. Mencari nafkah bukanlah tanggung jawab mutlak perempuan. Adanya anggapan semacam itu menyebabkan orang tua menomorduakan pendidikan perempuan.

Gender merupakan perbedaan perilaku antara laki-laki dan perempuan yang dikonstruksi secara sosial, yakni perbedaan yang diciptakan oleh manusia (bukan kodrat) melalui proses sosial dan kultural yang panjang. Women's Studies Encyclopedia dalam Abdul Latief, Siti Maryam, dan Muh. Yusuf dijelaskan bahwa gender adalah suatu konsep kultural yang berupaya membuat pembedaan dalam hal peran, perilaku, mentalitas, dan karakteristik antara laki-laki dan perempuan yang berkembang dalam masyarakat. Dengan demikian, secara umum dapat dikatakan bahwa gender dapat dikatakan tidak berlaku universal. Artinya setiap masyarakat pada waktu tertentu, memiliki sistem kebudayaan (cultural systems) tertentu yang berbeda dengan masyarakat lain dan waktu yang lain pula. Dalam system kebudayaan ini mencakup elemen deskriptif dan preskriptif, yaitu mempunyai citra yang jelas tentang bagaimana sebenarnya dan seharusnya laki-laki dan perempuan itu. $^{13}$

Sejalan dengan itu, Marianne Weber berpendapat bahwa laki-laki dan perempuan mempunyai kapasitas yang sama besar. Perempuan juga bisa melakukan berbagai hal yang bisa dilakukan oleh laki-laki, namun perempuan tidak punya waktu yang cukup untuk itu semua. Mereka harus membagi waktu untuk berbagai hal. Meskipun perempuan bekerja, namun mereka tetap harus mengurus rumah tangga dan memelihara anak. Berbeda halnya dengan laki-laki. Laki-laki leluasa mengembangkan karir tanpa harus memikirkan rumah tangga, bahkan perempuan juga diharapkan berpartisipasi untuk mendukung kesuksesan laki-laki. Potensi perempuan yang cukup baik harus kalah karena adanya kenyataan bahwa perempuan punya berbagai kewajiban dan kelemahan. Mereka harus melahirkan, mengurus anak dan mengurus rumah tangga. Ketika mereka bekerja berbagai bentuk pelecehan

\footnotetext{
${ }^{13}$ Abdul Latief, Siti Maryam, dan Muh. Yusuf. Kesetaraan Gender Dalam Budaya Sibaliparri Masyarakat Mandar. PEPATUDZU: Media Pendidikan dan Sosial Kemasyarakatan Vol. 15, No. 2, November 2019), 161.
} 
sudah menghadang. Mereka kadang-kadang mengalami gangguan pribadi dan gangguan seksual di tempat kerja. ${ }^{14}$

Berdasarkan hal tersebut maka struktur masyarakat dan norma-norma yang tertanam dalam masyarakat, bisa dipahami jika timbul ketimpangan dalam masyarakat. Laki-laki menjadi penghuni kelas satu karena sejak mereka lahir hal itu sudah ditanamkan, baik oleh keluarga maupun masyarkat. Perempuan dianggap kaum lemah dan menduduki posisi subordinat. Laki-lakilah yang kuat dan mampu menyelesaikan masalah, termasuk pekerjaan dengan lebih baik. Sebetulnya perempuan punya potensi yang tidak kalah jika dibandingkan dengan potensi pria, namun mereka ragu-ragu dalam mengembangkan diri karena ada norma-norma yang memojokan dirinya. Perempuan seringkali masih dibingungkan oleh berbagai masalah yang muncul sebagai akibat dari peran gandanya.

\section{B. Perempuan dan Perdagangan}

Data statistik yang dipublikasikan BPS (Badan Pusat Statistik) selalu menunjukan bahwa sektor jasa baik di desa maupun di kota selalu di dominasi oleh perempuan. Sektor jasa yang meliputi beberapa lapangan pekerjaan, ternyata didominasi oleh perdagangan. Mengenai keterlibatan perempuan disektor ini, Hans Dieter Evers menyatakan bahwa akses yang dimiliki dan relatif rendahnya tuntutan dari sektor ini telah mendorong perempuan untuk masuk ke dalamnya. Selain itu, kapasitas penyerapan yang sangat tinggi di sektor perdagangan telah mendorong perempuan untuk terjun ke dalamnya. Pola distribusi perdagangan menggambarkan rantai distribusi suatu komoditas dari produsen hingga ke konsumen akhir pada suatu wilayah yang melibatkan pelaku kegiatan perdagangan. ${ }^{15}$

Hasil penilitian Jatinom (Jawa Tengah) menunjukan bahwa pilihan perempuan untuk terlibat di sektor perdagangan merupakan salah satu alternatif yang dapat dilakukan ketika mereka harus mencukupi kebutuhan rumah tangganya. Seorang perempuan di daerah pedesaan yang sumber pendapatan suaminya dari sektor pertanian harus mampu mengelola pendapatan tersebut dengan sebaik-

\footnotetext{
${ }^{14}$ Marianne Weber. https://id.wikipedia.org/wiki/Marianne_Weber Diakses tanggal 20 Desember 2020.

${ }^{15}$ Badan Pusat Statistik. https://www.bps.go.id/publikasi.html diakses tanggal 20 Desember 2020.
} 
baiknya. Panen di sektor pertanian yang datangnya relatif lama yakni sekitar $3-4$ bulan, memaksa mereka untuk mencari alternatif lain agar dapat memenuhi kebutuhan sehari-har. Perempuan sebagai salah satu unsur rumah tangga juga harus mampu memperoleh penghasilan.

Menurut Ni Made Wiasti keterlibatan perempuan sebagai pedagang sayur di pasar Baturiti sangat dominan. Hal ini disebabkan selain tergeserya pekerjaannya perempuan di sektor pertanian, kondisi ini juga pertanda pembagian jenis pekerjaan berdasarkan jenis kelamin, yakni laki-laki di bidang pertanian dan perempuan di bidang perdagangan. Pekerjaan berdagang dianggap lebih cocok bagi perempuan karena pekerjaan ini sesuai dengan simbol-simbol keperempuanan, seperti fisik yang lemah, sifat telaten dan sabar. Berbeda dengan pekerjaan di bidang pertanian yang membutuhkan kemampuan fisik yang lebih besar dan yang secara alamiah tidak dimiliki oleh perempuan, seperti membajak sawah. Namum perempuan masih bisa terlibat dalam sektor pertanian seperti membersihkan gulma, menanam padi dan memanen padi. Di samping berpengaruh terhadap pola pembagian kerja rumah tangga, keterlibatan perempuan pedagang sayur di pasar, juga membawa pengaruh terhadap pola pengambilan keputusan di dalam rumah tangga. Pada keluarga perempuan pedagang sayur pola pengambilan keputusan yang berkaitan dengan kepentingan seluruh keluarga biasanya melibatkan suami, istri dan anak-anak dewasa. Begitu pula keputusan yang diambil merupakan kesepakatan bersama. baik itu menyangkut keputusan yang diambil, maupun yang berhak menentukan keputusan terakhir. Dalam hal ini tampak suara perempuan (istri) pedagang sayur cukup didengar, bahkan untuk keputusan tertentu, terutama terkait dengan kebutuhan rumah tangga otoritas penuh pada perempuan (istri). ${ }^{16}$

Dorongan yang mengharapkan perempuan untuk terjun bersama suami menopang kehidupan rumah tangganya tampak sangat besar di daerah pedesaan. Sumbangan perempuan yang cukup tinggi terhadap ekonomi rumah tangga ditunjukan dengan munculnya kategori budaya tentang sumbangan suami maupun isteri. Berbagai studi tentang perempuan ditegaskan bahwa status perempuan di Indonesia pada umumnya agak tinggi, karena peranan perempuan di bidang ekonomi

\footnotetext{
${ }^{16}$ Menurut Ni Made Wiasti. Perempuan Berpeluh Yang Tak Mengeluh: Studi Tentang Perempuan Pedagang Sayur Di Pasar Baturiti, Tabanan, Bali, 4.
} 
sangat penting. Tanggung jawab perempuan terhadap pendapatan rumah tangga mencerminkan posisi ekonomi yang kuat, baik di sektor pertanian maupun perdagangan. Menurut Yusuf, perempuan merupakan bintang baru dalam perkembangan ekonomi karena semakin banyak perempuan yang terjun ke dunia bisnis, baik dalam skala mikro, menengah, maupun besar. studi yang dilakukannya berusaha menghubungkan bias gender dengan subkultur, seperti asal daerah, etnisitas, dan praktik religius dalam konteks budaya nasional yang mempengaruhi kewiraswastaan di negaranegara berkembang. Hasilnya, mengidentifikasi bahwa gender, etinisitas, dan agama memainkan peran penting dalam perkembangan kewiraswastaan. Wiraswastaan perempuan memiliki tempat sendiri. Dilandasi motivasi mempertahankan hidup dan kemandirian, wiraswastaan perempuan menciptakan banyak peluang kerja dan peningkatan pendapatan. ${ }^{17}$

Kontribusi ekonomi perempuan salah satu tujuan seseorang bekerja adalah untuk mendorong perempuan sebagai penunjang perekonomian rumah tangga menjadi sangat penting dan ikut serta berperan dalam sektor ekonomi untuk menambah penghasilan keluarga untuk memenuhi umumnya peran perempuan secara ekonomi adalah menambah penghasilan keluarga. Karena itu, penghasilan tambahan dari aktivitas ekonomi perempuan dapat membantu mengentaskan keluarga dalam keluarga erat hubungannya dengan struktur lapangan pekerjaan yang ada dalam masyarakat luas. ${ }^{18}$

Ani Rostiyati menyatakan bahwa semua orang mampu menikmati modernisasi dan kemajuan teknologi yang ada. Tujuan wanita pedesaan berdagang ke pasar tidak semata-mata berkaitan dengan keuntungan yang akan diperolehnya, tetapi sebagai sebuah institusi juga merupakan wahana untuk menjalin hubungan antara penjual dan pembeli. Gambaran ini telah dperlihatkan oleh Palttner pada saat ia mengatakan bahwa pola hubungan antara penjual dan pembeli maupun orangorang yang terlibat dalam kegiatan pasar, selain bersifat impersonal juga personal. Arifin menyatakan bahwa masyarakat nelayan adalah sekelompok masyarakat yang

\footnotetext{
${ }^{17}$ Siti Nurjannah dan Siti Aisyah. Gender: Kedudukan Perempuan Dalam Sektor Ekonomi Negara Perspektif Islam, 2019), 10.

${ }^{18}$ Fatimah Depi Susanti. Kontribusi Perempuan Parengge-Rengge dalam Ekonomi Keluarga. Sosial Budaya, Vol. 10 No. 01 Januari - Juni 2013, 48.
} 
tinggal di wilayah pantai atau pesisir yang hidup bersama dan memenuhi kebutuhan hidupnya dari sumber daya laut. Masyarakat yang hidup di permukiman pantai atau pesisir memiliki karakteristik secara sosial ekonomis sangat terkait dengan sumber perekonomian dari wilayah laut. ${ }^{19}$ Senada dengan pendapat Ani Rostiyati bahwa masyarakat pesisir yang di dominasi oleh usaha perikanan pada umumnya masih berada pada garis kemiskinan, mereka tidak mempunyai pilihan mata pencaharian, memiliki tingkat pendidikan yang rendah, tidak mengetahui dan menyadari kelestarian sumber daya alam. Lingkungan alam sekitar akan membentuk sifat dan perilaku masyarakat. ${ }^{20}$

Wanita datang ke pasar baik sebagai pedagang maupun pembeli tidak hanya didasarkan pada dorongan-dorongan ekonomi semata, tetapi juga sebagai suatu wahana pemenuhan berbagai kebutuhan mereka seperti saling tukar informasi, rekreasi dan mejalin hubungan sosial. Di pasar, perempuan pedagang mempunyai kebebasan untuk mengekspresikan kemampuannya dalam bentuk tawar-menawar sampai akhirnya si penjual mampu meyakinkan pembelinya bahwa harga yang ditawarkan sangat murah, dan seolah-olah si penjual tidak memperoleh keuntungan sama sekali. Kedaan ini dapat dibandingkan dengan sambung ayam yang ada di Bali: kepuasan diperoleh bukan pada kemenangan dan banyaknya uang yang diterima oleh pemenang, tetapi sabung ayam juga berfungsi sebagai wahana untuk menunjukan kekuatan/keperkasaan laki-laki terhadap lawannya. ${ }^{21}$ Wanita pedagang juga menduduki lapisan-lapisan sosial tertentu di pasar. Lapisan sosial selain ditentukan oleh jenis komoditi yang dipasarkan, juga didasarkan pada besarnya kekayaan yang mereka miliki.

Pasar di Indonesia merupakan salah satu penyumbang yang besar dalam pemasukan negara. Pasar merupakan tempat bertemunya pembeli dan penjual untuk melakukan transaksi jual beli barang atau jasa. Menurut ilmu ekonomi, pasar berkaitan dengan kegiatannya bukan tempatnya. Ciri khas sebuah pasar adalah adanya kegiatan transaksi atau jual beli. Para konsumen datang ke pasar untuk

\footnotetext{
${ }^{19}$ Arifin, Taslim. Nelayan Kemiskinan dan Pembangunan. Makassar: Masagena Press, 2006.

${ }^{20}$ Ani Rostiyati. Peran Ganda Perempuan Nelayan di Desa Muara Gading Mas Lampung Timur. Patanjala Vol. 10 No. 2 Juni 2018.

${ }^{21}$ Sabung Ayam Menurut Hukum Adat Bali http://ehttp://repository.umy.ac.id/bitstream/handle/123456789/31311/BAB\%20III.pdf?sequence=7\&isAllow ed=y diakses tanggal 9 Nopember 2020.
} 
berbelanja dengan membawa uang untuk membayar harganya. Pasar tradisional adalah pasar yang pelaksanaannya bersifat tradisional, tempat bertemunya antara para penjual dengan pembeli, terjadinya kesepakatan harga dan terjadinya transaksi setelah melalui proses tawar-menawar harga. Biasanya pasar tradisional menyediakan berbagai macam bahan pokok keperluan rumah tangga, biasanya berlokasi di tempat yang terbuka. Bangunan di pasar tradisional berbentuk toko dan kios. Toko semi permanen umumnya digunakan untuk berjualan aneka kue, pakaian, dan barang atau perabotan lainnya; sedangkan los digunakan untuk berjualan buahbuahan, sayuran, ikan, daging dan sebagainya. Saat ini kebersihan di pasar tradisional sudah mulai ditingkatkan, bahkan sekarang ada pasar tradisional yang rapi dan bersih sehingga nyaman untuk dikunjungi. ${ }^{22}$

Terait dengan perdagangan sebagai pekerjaan, beberapa penelitian yang membahas keterlibatan perempuan dalam berbagai jenis pekerjaan pernah dilakukan oleh Kralawi Sita, dan Erna Herawati menemukan bahwa relasi gender dalam kegiatan pemetikan teh di Perkebunan teh Gambung menempatkan pemetik laki-laki dan perempuan mempunyai akses yang sama. Akan tetapi partisipasi mereka dibagi berdasarkan gender dan dipengaruhi budaya patriarki. Perempuan mempunyai partisipasi yang besar dalam kegiatan pemetikan manual dan gunting, sedangkan laki-laki mendominasi pemetikan dengan menggunakan mesin petik (pemetikan mekanis). Pemetikan mekanis belum sepenuhnya memberikan kesempatan bagi perempuan untuk terlibat dikarenakan alat mesin petik yang tidak ergonomis bagi perempuan atau belum berperspektif gender. Namun secara keseluruhan, relasi gender di Perkebunan teh Gambung telah mampu memberikan kesempatan bagi pemetik perempuan untuk turut mengakses dan mengontrol sebagian sumberdaya secara adil dan setara dengan pemetik laki-laki. ${ }^{23}$

Penelitian Triyono dan Septiana Wijayanti tentang perempuan pekerja di kebun karet. Penelitian tersebut mengungkap bahwa kehidupan para perempuan yang

\footnotetext{
${ }^{22}$ Triyono dan Septiana Wijayanti. Pola Kegiatan Perempuan Pedagang Sayur Di Pasar Gabus Jatinom Kabupaten Klaten. (Magistra No. 101 Th. XXIX September 2017), 45.

${ }^{23}$ Kralawi Sita, dan Erna Herawati. Relasi Gender Pada Pekerja Pemetikan Teh: Studi Kasus Pembagian Kerja Dan Relasi Gender Di Perkebunan Teh Gambung, Jawa Barat. https://media.neliti.com/media/publications/180913-ID-none.pdf, diakses tanggal 27 Desember 2020. 6
} 
bekerja di perusahaan besar perkebunan yang serba diatur kegiatannya termasuk dalam rutinitas setiap hari dan berulang-ulang secara terus menerus, terdapat pembagian kerja berdasarkan gender di perkebunan maupun di luar perkebunan, serta adanya ideologi yang melandasi. ${ }^{24}$

Berdasarkan hal tersebut bahwa kontribusi ekonomi perempuan yang terjun ke dunia bisnis, baik dalam skala mikro, menengah, maupun besar terbilang cukup baik, namun perhatian pemerintah diperlukan untuk meningkatkan produktivitas perempuan dalam kegiatan ekonomi setempat. Pemberdayaan perempuan sangat diperlukan disebabkan karena kurangnya ilmu pengetahuan dan kemiskinan yang selalu mengukung mereka, sedangkan beban kerja dalam keluarga cukup tinggi. Keberadaan laki-laki dan perempuan bukan dipahami sebagai sesuatu yang dipertentangkan (dikotomis), tetapi sebagai hal yang berpasangan.

\section{Gender Dalam Pembangunan}

Pembahasan soal gender, praktisi pembangunan dan aktivis gerakan sosial memperhatikan kesenjangan yang ada di antara laki-laki dan perempuan dalam hal hak-hak, tanggung jawab, akses dan penguasaan terhadap sumber daya alam serta pengambilan keputusan dalam keluarga, di komunitas dan di tingkat nasional. Lakilaki dan perempuan kerapkali memiliki perbedaan dalam prioritas, hambatan dan pilihan terkait dengan pembangunan serta dapat mempengaruhi dan dipengaruhi secara berbeda oleh proyek-proyek pembangunan dan penanganan kampanye. Untuk meningkatkan efektivitas, pertimbangan-pertimbangan tersebut perlu disikapi dalam semua perencanaan dan penanganan program dan kampanye. Jika pertimbanganpertimbangan tersebut tidak disikapi secara serius dan memadai, tindakan-tindakan tersebut tidak saja hanya akan menghasilkan inefisiensi serta tidak berkelanjutan, tetapi juga dapat memperburuk kondisi ketidaksetaraan yang ada. Memahami isu gender dapat memungkinkan proyek untuk memperhatikan persoalan gender dan

\footnotetext{
${ }^{24}$ Triyono dan Septiana Wijayanti. Pola Kegiatan Perempuan Pedagang Sayur Di Pasar Gabus Jatinom Kabupaten Klaten, 5.
} 
membangun kapasitas untuk menghadapi dampak-dampak ketidaksetaraan dan untuk memastikan adanya keberlanjutan. ${ }^{25}$

Menurut Ratih Probosiwi bahwa banyak studi telah dilakukan dalam rangka membahas program pembangunan pemerintah yang menjadi sebab kemiskinan kaum perempuan. Misalnya, program swa-sembada pangan atau revolusi hijau (green revolution) secara ekonomis telah menyingkirkan kaum perempuan dari pekerjaannya sehingga memiskinkan mereka. Di Jawa misalnya, program revolusi hijau dengan memperkenalkan jenis padi unggul yang tumbuh lebih rendah, pendekatan panen dengan sistem tebang menggunakan sabit, tidak memungkinkan lagi penggunaan aniani, padahal alat tersebut melekat dan digunakan oleh kaum perempuan. Akibatnya banyak kaum perempuan miskin di desa termarginalisasikan, yakni semakin miskin dan tersingkir karena tidak mendapatkan pekerjaan di sawah pada musim panen. Berarti revolusi hijau dirancang tanpa mempertimbangkan aspek gender. $^{26}$

Hal yang harus diperjuangkan gender mengacu pada atribut, peluang sosial, dan hubungan yang terkait dengan laki-laki dan perempuan. Atribut, peluang dan hubungan ini dibangun dan dipelajari secara sosial melalui proses sosialisasi. Gender mengacu pada atribut, harapan, dan norma sosial, perilaku, dan budaya yang terkait dengan menjadi perempuan atau laki-laki (UN Women dalam World Bank). ${ }^{27}$ Istilah gender seringkali disamaartikan dengan jenis kelamin. Padahal keduanya merupakan hal yang berbeda. Jenis kelamin sendiri mengacu pada kondisi fisik yang secara lahiriah dimiliki oleh seseorang. Ketika seseorang terlahir sebagai laki-laki atau perempuan, terdapat perbedaan norma dan perilaku antar keduanya. Perbedaan perlakuan inilah yang kemudian membentuk peran, perilaku, dan atribut yang dikonstruksikan secara sosial dalam masyarakat yang seringkali disebut dengan

${ }^{25}$ Gender dan Pembangunan: konsep-konsep Dasar. Buletin DTE edisi khusus No 99-100, Oktober 2014. https://www.downtoearth-indonesia.org/sites/downtoearth-indonesia.org/files/99-100Ina.pdf diakses tanggal 20 Desember 2020.

${ }^{26}$ Ratih Probosiwi. Perempuan Dan Perannya Dalam Pembangunan Kesejahteraan Sosial (Women And Its Role On Social Welfare Development) NATAPRAJA Vol. 3 No. 1, Mei 2015, 47.

${ }^{27}$ World Bank. Gender Differences in Employment and Why They Matter. World Development Report 2012). 
gender. ${ }^{28}$ Isu gender merupakan suatu isu yang menuntut keadilan konstruksi sosial maupun kultural antara kaum laki-laki dengan perempuan. Dalam tuntutan konstruksi ini, keseimbangan fungsi, status, dan hakekat antar jenis kelamin diharapkan dapat direalisasikan. Sebaliknya, pembangunan merupakan suatu konstruksi perubahan yang terjadi di masyarakat dari kondisi sosio-kultural tertentu menuju ke arah sesuatu yang dianggap lebih bernilai. Selain itu dapat juga diartikan sebagai usaha pengentasan keterbelakangan. Oleh karena itu semua, gender dan pembangunan adalah suatu korelasi timbal balik antara satu dengan yang lain. ${ }^{29}$

Menurut pandangan feminisme, gender memainkan peran penting tidak hanya di ranah rumah tangga tetapi juga kancah politik internasional. Seperti yang dipaparkan oleh Viotti dan Kauppi bahwa teori-teori besar gagal dalam menangkap isu yang berada di tingkat individu. Selain itu, teori besar seperti realisme dan liberalisme cenderung mengabaikan ketimpangan gender yang terlalu berfokus pada budaya patriarki. Asumsi besar lainnya yang dipaparkan oleh kaum feminisme adalah pengembangan emansipasi perempuan dengan menghapuskan ketimpangan gender yang diakibatkan oleh budaya patriarki. Menurut asumsi feminisme, ketimpangan gender tersebut luput dari pandangan mahzab besar seperti realisme. Adapun sebagian besar feminisme menolak metodologi positivisme dan memilih menggunakan pendekatan konstruktivis bahwa pengetahuan dibentuk oleh konstruksi budaya, sejarah dan konteks (Viotti and Kauppi). ${ }^{30}$

Selain itu, salah satu yang juga menjadi kajian utama feminisme ialah peran domestik yang dimainkan oleh perempuan. Dalam buku A Cultural History of Women in the Modern Age, dinyatakan bahwa perempuan, terutama yang telah berkeluarga, harus menyalurkan perhatiannya pada urusan domestik, yakni pekerjaan rumah dan anak-anak. Walaupun begitu, dari dekade ke dekade, pandangan mengenai peran perempuan yang tidak hanya pada ranah domestik

\footnotetext{
${ }^{28}$ Iqbal Ramadhan dan Innesia Maeesumah. Mengkaji Peran Un Women Dalam Mengatasi Kekerasan Terhadap Perempuan Dan Mewujudkan Kesetaraan Gender Melalui Perspektif Feminisme (Jurnal Asia Pacific Studies Volume 2 Number 2 / July - December, 2018). 155

${ }^{29}$ Ulfatun Hasanah, Najahan Musyafak. Keterlibatan Perempuan dalam Pembangunan Politik. (Sawwa: Jurnal Studi Gender, Vol 12, No 3, 2017).

${ }^{30}$ Viotti, Paul R. and Kauppi, Mark V. International Relations Theory 5th Edition. (England: Pearson, 2014).
} 
melainkan pada politik praktis, telah mulai dipertimbangkan banyak orang. Ketimpangan dan diskriminasi kerap kali dirasakan karena partisipasi perempuan dalam sektor ekonomi dengan menjadi buruh, umumnya harga dihargai dengan upah yang kecil, terlepas dari beban pekerjaan yang sama seperti yang dilakukan oleh laki-laki. Hal ini yang kemudian pelatuk akan terciptanya gerakan-gerakan perempuan yang mempertanyakan nilai dan norma mereka dalam kehidupan sosial (Hannam). ${ }^{31}$ Oleh karena itu, peningkatan peranan perempuan dan laki-laki dalam pembangunan yang berwawasan gender sebagai bagian integral dari pembangunan nasional, mempunyai arti penting dalam upaya untuk mewujudkan kemitrasejajaran yang harmonis antara laki-laki dengan perempuan atau mewujudkan kesetaraan dan keadilan gender dalam berbagai bidang kehidupan dan pembangunan. Hasil penelitian ini, berusaha menampakkan gender dalam pembangunan tidak harus sama peran antara laki-laki dan perempuan, ada wilayah-wilayah sendiri yang bisa dilakukan laki-laki dan perempuan.

Lebilanjut dikatakan bahwa Ratih Probosiwi bahwa gender berkaitan dengan konstruksi sosial terhadap perempuan . Masyarakat sering menganggap perempuan sebagai kelompok masyarakat lemah dan terbatas untuk melakukan pekerjaanpekerjaan domestik atau rumah tangga. Sedangkan laki-laki sebagai makhluk yang superior dan bertugas untuk urusan-urusan non domestik. Dalam pandangan tradisi patriarkhi, perempuan secara struktural berada di bawah lakilaki, dan kondisi ini secara struktural dan kultural tidak menguntungkan kaum perempuan. Pendekatan ini memahami tujuan pembangunan bagi perempuan dalam pengertian kemandirian dan kekuatan internal, dan sedikit banyak lebih menekankan pada pembuatan undangundang yang berkenaan dengan kesamaan antara laki-laki dan perempuan ketimbang pemberdayaan perempuan itu sendiri untuk berusaha mengubah dan mentransformasikan struktur yang sangat bertentangan dengan mereka. Pendekatan ini mengakui perlunya pembuatan undang-undang yang bersifat mendukung, berpendapat bahwa perkembangan organisasi perempuan, yang mengarah pada

\footnotetext{
${ }^{31}$ Hannam, J. Power: Women, Politics, and Power in Europe after 1920. In Connor, L. A Cultural History of Women in Modern Age. (United Kingdom: Bloomsbury Academic, 2016).
} 
mobilisasi politik, peningkatan kesadaran dan pendidikan rakyat, merupakan syarat penting bagi perubahan sosial yang berkelanjutan. ${ }^{32}$

Pada saat manusia masih berpikir dengan sangat sederhana, mereka belajar dari apa yang mereka lihat dalam hidup. Mereka membutuhkan pembagian kerja untuk kelangsungan hidup, kemudian dimulailah pembagian kerja atas dasar biologis. Sejarah mencatat bahwa pada zaman ini, terjadi pembagian kerja berdasarkan jenis kelamin. Dari sini kemudian muncul perbedaan jenis pekerjaan luar (publik) dan pekerjaan dalam (domestik). Tersosialisasi oleh lingkungan hidupnya, maka hidup perempuan cenderung berkelompok, mengelola makanan dan obat-obatan. Ini berbeda dengan laki-laki yang bekerja diluar dengan bebas. Lingkungan hidup laki-laki mensosialisasikan hidupnya berpindah-pindah.

Berdasarkan hal tersebut meningkatkan kesetaraan gender dan peran perempuan dalam pembangunan, Indonesia harus menghadapi banyak sekali tantangan. Oleh karena itu, peningkatan peranan perempuan dan laki-laki dalam pembangunan yang berwawasan gender sebagai bagian integral dari pembangunan nasional, mempunyai arti penting dalam upaya untuk mewujudkan kemitrasejajaran yang harmonis antara laki-laki dengan perempuan untuk mewujudkan kesetaraan dan keadilan gender dalam berbagai bidang kehidupan dan pembangunan.

\section{PENUTUP}

Pekerjaan yang selama ini hanya dikerjakan kaum laki-laki dan ditabuhkan bagi mereka, kini bisa dan lumrah dikerjakan oleh kaum perempuan. Pergeseran ini dapat dilihat melalui semakin banyaknya jumlah perempuan yang merambah wilayah publik, bahkan rela meninggalkan rumah untuk memperoleh pekerjaan. Hal ini dibuktian dengan diadakannya Konferensi Perempuan IV Sedunia di Beijing pada tahun 1995 yang merumuskan tentang penolakan terhadap ajaran agama yang memandang eksistensi perempuan dengan sebelah mata dan Konferensi Durban pada tahun 2001 tentang diskriminasi gender. Tanggungjawab perlindungan, keamanan, kesejahteraan, dan nafkah untuk keluarga yang dulu berada dipundak laki-laki, kini juga telah diperankan oleh perempuan.

\section{$2015,48$.}

${ }^{32}$ Ratih Probosiwi. Perempuan Dan Perannya Dalam Pembangunan Kesejahteraan Sosial, 
Kontribusi ekonomi perempuan salah satu tujuan bekerja adalah untuk mendorong perempuan sebagai penunjang perekonomian rumah tangga menjadi sangat penting dan ikut serta berperan dalam sektor ekonomi untuk menambah penghasilan keluarga dan peran perempuan secara ekonomi menambah penghasilan keluarga.

Peningkatan peranan perempuan dan laki-laki dalam pembangunan yang berwawasan gender sebagai bagian integral dari pembangunan nasional, mempunyai arti penting dalam upaya untuk mewujudkan kemitrasejajaran yang harmonis antara laki-laki dengan perempuan untuk mewujudkan kesetaraan dan keadilan gender dalam berbagai bidang kehidupan dan pembangunan.

\section{DAFTAR PUSTAKA}

Ani Rostiyati. Peran Ganda Perempuan Nelayan di Desa Muara Gading Mas Lampung Timur. Patanjala Vol. 10 No. 2 Juni 2018.

Arifin, Taslim. Nelayan Kemiskinan dan Pembangunan. Makassar: Masagena Press, 2006.

A. Fitri. Balasong, Imaji; Sketsa Pergelakan Batin Perempuan. (Cet. I. Makassar: Pustaka Sawerigading, 2008.

Amiruddin Mustam. Budayagender Dalam Masyarakat Perspektiftemporal Ekologi Dan Sosial Ekonomi. Jurnal Al-Maiyyah, Volume 10 No. 1 Januari-Juni 2017.

Fatimah Depi Susanti. Kontribusi Perempuan Parengge-Rengge dalam Ekonomi Keluarga. Sosial Budaya, Vol. 10 No. 01 Januari - Juni 2013.

Gibson, Ivancevich, Donnell. Organisasi. Perilaku Struktur dan Proses. Edisi kedelapan, Jilid 1, 2002.

Gender dan Pembangunan: konsep-konsep Dasar. Buletin DTE edisi khusus No 99100, Oktober 2014. https://www.downtoearthindonesia.org/sites/downtoearth-indonesia.org/files/99-100-Ina.pdf diakses tanggal 20 Desember 2020.

Hannam, J. Power: Women, Politics, and Power in Europe after 1920. In Connor, L. A Cultural History of Women in Modern Age. (United Kingdom: Bloomsbury Academic, 2016. 
Iqbal Ramadhan dan Innesia Maesumah. Mengkaji Peran Un Women Dalam Mengatasi Kekerasan Terhadap Perempuan Dan Mewujudkan Kesetaraan Gender Melalui Perspektif Feminisme (Jurnal Asia Pacific Studies Volume 2 Number 2 / July - December, 2018.

Imam Mahdi. Konsep gender pada masyarakat adat suku semendo kabupaten muara enim (studi kasus pada adat tunggu tubang. (Jurnal Hawa Vol. 1 No. 1 Januari-Juni 2019.

J.S. Hyde and M.C. Linn, The Psychology of Gender. Advance through MetaAnalysis (Baltimore: Johns Hopkins University Press, 1986.

Kralawi Sita, dan Erna Herawati. Relasi Gender Pada Pekerja Pemetikan Teh: Studi Kasus Pembagian Kerja Dan Relasi Gender Di Perkebunan Teh Gambung, Jawa Barat. https://media.neliti.com/media/publications/180913-ID-none.pdf, diakses tanggal 27 Desember 2020.

Marianne Weber. https://id.wikipedia.org/wiki/Marianne_Weber Diakses tanggal 20 Desember 2020.

Mujahidah. Dinamika Gender Dan Peran Perempuan Dalam Ekonomi Keluarga. Jurnal Al- Ulum Volume. 10, Nomor 1, Juni 2010.

Prof. Irwan Abdullah. Kupas Strategi Penulisan dan Penelitian Gender 2019. https://iainkudus.ac.id/temp/u01/list.php?pag=detail\&idb=56064, diakses tgl 27 Desember 2020.

Ratih Probosiwi. Perempuan Dan Perannya Dalam Pembangunan Kesejahteraan Sosial (Women And Its Role On Social Welfare Development) NATAPRAJA Vol. 3 No. 1, Mei 2015.

Sabung Ayam Menurut Hukum Adat Bali http://repository.umy.ac.id/bitstream/handle/123456789/31311/BAB\%20III.p df?sequence $=7 \&$ isAllowed $=y$ diakses tanggal 9 Nopember 2020 .

Triyono dan Septiana Wijayanti. Pola Kegiatan Perempuan Pedagang Sayur Di Pasar Gabus Jatinom Kabupaten Klaten . (Magistra No. 101 Th. XXIX September 2017.

Ulfatun Hasanah dan Najahan Musyafak. Gender And Politics: Keterlibatan Perempuan Dalam Pembangunan Politik SAWWA - Volume 12, Nomor 3, Oktober 2017.

UN Women. Monitoring Gender Equality and Empowerment of Women and Girls in the 2030 Agenda for Sustainable Development: Opportunities and Challenges, 2015. 
Viotti, Paul R. and Kauppi, Mark V. International Relations Theory 5th Edition. England: Pearson, 2014.

Wery Gusmansyah. Dinamika Kesetaraan Gender dalam Kehidupan Politik Di Indonesia. Jurnal Hawa : Studi Pengarus Utamaan Gender dan Anak. Jurnal Hawa Vol 1, No 1, 2019.

World Bank. Gender Differences in Employment and Why They Matter. World Development Report 2012. 